\title{
Pengaruh Spiritualitas Kerja terhadap Keterlekatan Karyawan melalui Kepuasan Kerja pada UKM Kota Bogor
}

\author{
Nur Janah \\ Sekolah Pascasarjana Departemen Manajemen \\ Fakultas Ekonomi dan Manajemen \\ Institut Pertanian Bogor \\ Email: haniyyahzahra@gmail.com \\ Anggraini Sukmawati \\ Dosen Departemen Manajemen, Fakultas Ekonomi dan Manajemen \\ Institut Pertanian Bogor \\ Email: anggrainism@gmail.com \\ Farit Mochamad Afendi \\ Dosen Departemen Manajemen, Fakultas Ekonomi dan Manajemen \\ Institut Pertanian Bogor \\ Email: Fmafendi@gmail.com
}

\begin{abstract}
The Quality human resources are needed in global economic competition. Spirituality in work becomes a solution developed by companies, because it can be created a conducive environment for employees to work as good as possible. The purpose of this study is to analyze the influence of work spirituality on employee engagement through job satisfaction in Small and Medium Enterprises cluster of food and beverages in the city of Bogor. This research used Structural Equation Modeling PLS for data analysis. Samples are SMEs that have at least 5 employees and have been registered in the Department of Industry and Trade (Disperindag) and the Department of Cooperatives and SMEs Bogor City. So that 25 SMEs are eligible, consisting of 65 people consisting of employees and owners of SMEs. Sampling method using purposive sampling. The results showed that the spirituality of work has a positive effect directly on employee engagement and indirectly influence through job satisfaction on employee engagement to the organization. Meanwhile, job satisfaction has a direct positive effect on employees' engagement to the organization. Therefore, increased employee engagement to SMEs is suggested through several supporting activities such as: communicating and facilitating the need for spirituality in the workplace.

Keywords: Spirituality of work, job satisfaction, employee engagement, partial least squares, structural equation modeling.
\end{abstract}

\section{ABSTRAK}

Sumber daya manusia yang berkualitas sangat diperlukan dalam menghadapi persaingan ekonomi global saat ini. Spiritualitas dalam pekerjaan menjadi solusi yang dikembangkan oleh perusahaan-perusahaan, karena dapat menciptakan keadaan yang kondusif bagi karyawan untuk bekerja sebaik mungkin. Tujuan dari penelitian ini adalah menganalisis pengaruh spiritualitas kerja terhadap keterlekatan karyawan melalui kepuasan kerja pada Usaha Kecil dan Menengah klaster makanan dan minuman di Kota Bogor. Penelitian ini menggunakan Structural Equation Modelling PLS untuk analisis data. Sampel adalah UKM yang memiliki minimal 5 orang karyawan dan telah terdaftar di Dinas Perindustrian dan Perdagangan (Disperindag) dan Dinas Koperasi dan UMKM Kota Bogor. Sehingga diperoleh 25 UKM yang memenuhi syarat, berjumlah 65 orang yang terdiri dari karyawan dan pemilik UKM. Metode pengambilan sampel menggunakan purposive sampling. Hasil penelitian menunjukkan bahwa spiritualitas kerja berpengaruh positif secara langsung terhadap keterlekatan 
karyawan dan berpengaruh tidak langsung melalui kepuasan kerja terhadap keterlekatan karyawan kepada organisasi. Sementara itu, kepuasan kerja berpengaruh positif secara langsung terhadap keterlekatan karyawan kepada organisasi. Oleh karena itu, peningkatan keterlekatan karyawan pada UKM disarankan melalui beberapa kegiatan penunjang antara lain: mengomunikasikan dan memfasilitasi kebutuhan spiritulitas di tempat kerja.

Kata kunci: Spiritualitas kerja, kepuasan kerja, keterlekatan karyawan, partial least squares, structural equation modelling.

\section{Pendahuluan}

Meningkatnya persaingan ekonomi global menuntut setiap perusahan untuk terus berupaya memanfaatkan semaksimal mungkin sumber daya yang dimiliki, agar dapat meningkatkan kinerja dan mampu bersaing di pasar global. Sumber daya yang berperan penting dan merupakan aset utama dalam perusahaan adalah sumber daya manusia (tenaga kerja). Hal ini dikarenakan tidak satu pun faktor dalam aktivitas bisnis yang mempunyai dampak langsung terhadap kesejahteraan perusahaan selain sumber daya manusia.

Menurut riset yang dilakukan oleh Gallup di Indonesia menunjukkan bahwa hampir 77 persen karyawan bekerja dalam kondisi normatif atau bekerja sebagai kewajiban transaksional. Dengan kata lain bekerja hanya semata untuk mendapatkan penghasilan bulanan tanpa ada keterlekatan karyawan (employee engagement) di dalamnya (Gallup 2013). Hasil jajak pendapat yang juga dilakukan oleh Gallup pada bisnis di Amerika Serikat, menemukan adanya kerugian produksi sebesar $\$ 300$ milyar per tahun yang dialami perusahaan sebagai akibat dari rendahnya keterlekatan karyawan dalam bekerja (Gallup 2005).

Dampak lain yang juga ditimbulkan dari rendahnya keterlekatan kerja adalah adanya efek negatif dari pekerjaan yang dijalani terhadap kesehatan fisik karyawan baik secara psikologis maupun medis, seperti stres, frustasi, kejengkelan dan amarah. Dimana kondisi yang tidak sehat tersebut membuat suasana bekerja tidak menyenangkan, tidak menantang, dan tidak menarik.

Pada sisi lain, ketika keterlekatan karyawan pada organisasi dapat ditangani dengan baik, maka akan memberikan sumbangan efektif sebesar 16 persen terhadap profitabilitas, 18 persen pada produktifitas, 25 persen terhadap penurunan tingkat turnover yang tinggi, 49 persen terhadap penurunan tingkat turnover yang rendah, 37 persen terhadap penurunan ketidak hadiran, dan 60 persen pada kualitas kerja (Harter et al 2002). Besarnya manfaat dan dampak yang ditimbulkan dari keterlekatan karyawan dalam organisasi, menjadi alasan terhadap pentingnya menumbuhkan keterlekatan karyawan pada pekerjaan dan organisasi.

Pengembangan spiritualitas di tempat kerja menjadi salah satu komponen potensial dalam membentuk rasa keterlekatan dan komunitas karyawan terhadap organisasi (Karakas 2010). Tingkat internalisasi kebutuhan spiritual mendorong seseorang untuk mencari arti tentang pekerjaan yang dilakukannya, mengapa dan untuk apa individu melakukan pekerjaan tersebut (Krishnakumar \& Neck 2002). Keterlekatan karyawan juga dapat tumbuh setelah karyawan merasa puas (Abraham 2012). Karena karyawan yang relatif puas dengan pekerjaannya akan lebih berkomitmen dan terikat dengan organisasi (Mathis \& Jackson 2011). 
Keterlekatan karyawan juga sangat dibutuhkan pada Usaha Kecil dan Menengah (UKM). Mengingat pentingnya peran UKM dalam sektor perekonomian di Indonesia, berupa percepatan pemerataan pertumbuhan ekonomi melalui penyediaan lapangan usaha dan lapangan kerja, peningkatan pendapatan masyarakat, serta berperan dalam peningkatan perolehan devisa dan memperkokoh struktur ekonomi nasional (Hubeis 2011).

Usaha Kecil dan Menengah (UKM) juga diperioritaskan sebagai salah satu fokus utama MEA (Masyarakat Ekonomi ASEAN) dalam pengembangan pemerataan ekonomi. Sehingga UKM dituntut untuk memiliki daya saing yang tinggi dan harus memperbaiki diri melalui peningkatan kinerja dan produktivitas. Namun, cepatnya tingkat turn over karyawan yakni berkisar 0-3 tahun menjadi penghambat bagi UKM untuk meningkatkan daya saing dan kinerja perusahaan. Tujuan penelitian ini adalah untuk menganalisis hubungan spiritualitas kerja dan kepuasan kerja dalam meningkatkan keterlekatan karyawan terhadap perusahaan serta menganalisisi hubungan di antara ketiga variabel tersebut.

\section{Metode Penelitian}

Pada tahap awal analisis deskriptif dilakukan terkait mengenai UKM makanan dan minuman. Tahap berikutnya, menentukan pengaruh dari spiritualitas kerja dan kepuasan kerja terhadap keterlekatan karyawan (employee engagement) pada UKM makanan dan minuman Kota Bogor. Teknik pengambilan sampel pada penelitian ini menggunakan purposive sampling, dimana pengambilan sampel ini dasarkan pertimbangan tertentu yakni: minimal memiliki 5 orang karyawan dan telah terdaftar di Dinas Perindustrian dan Perdagangan (Disperindag) atau Dinas Koperasi dan UMKM Kota Bogor. Berdasarkan kriteria tersebut, terdapat 25 UKM yang memenuhi kriteria. Dan dari 125 kuesioner yang disebar, hanya 65 kuesioner yang terisi dan layak untuk dianalisis.

Metode analisis penelitian ini menggunakan pendekatan permodelan. Permodelan berfungsi untuk melihat hubungan antar peubah laten, antar indikator dan antar keduanya dengan menggunakan Structural Equation Modeling Partial Least Square (SEM PLS). PLS digunakan untuk menganalisis konstruk yang dibentuk dengan indikator reflektif dan formatif (Latan \& Ghozali 2012).

Penelitian ini menggunakan tiga peubah yaitu spiritualitas kerja, kepuasan kerja, dan keterlekatan karyawan. Indikator keterlekatan karyawan diadaptasi dari Utrecht Work Engagement Scale (UWES) (Schaufeli et al 2002), yaitu: 1) vigor; 2) dedication; 3) absorption. Indikator kepuasan kerja diadopsi dari Luthans (2006), yaitu: 1) pembayaran upah dan gaji; 2) pekerjaan itu sendiri; 3) rekan kerja; 4) promosi pekerjaan; 5) penyeliaan (supervisi). Sedangkan indikator spiritualitas kerja diadaptasi dari Milliman et al. (2003) yaitu 1) meaningful work; 2) sense of community; dan 3) alignment with the organization's values. Kerangka Pemikiran Penelitian dijelaskan pada Gambar 1. 


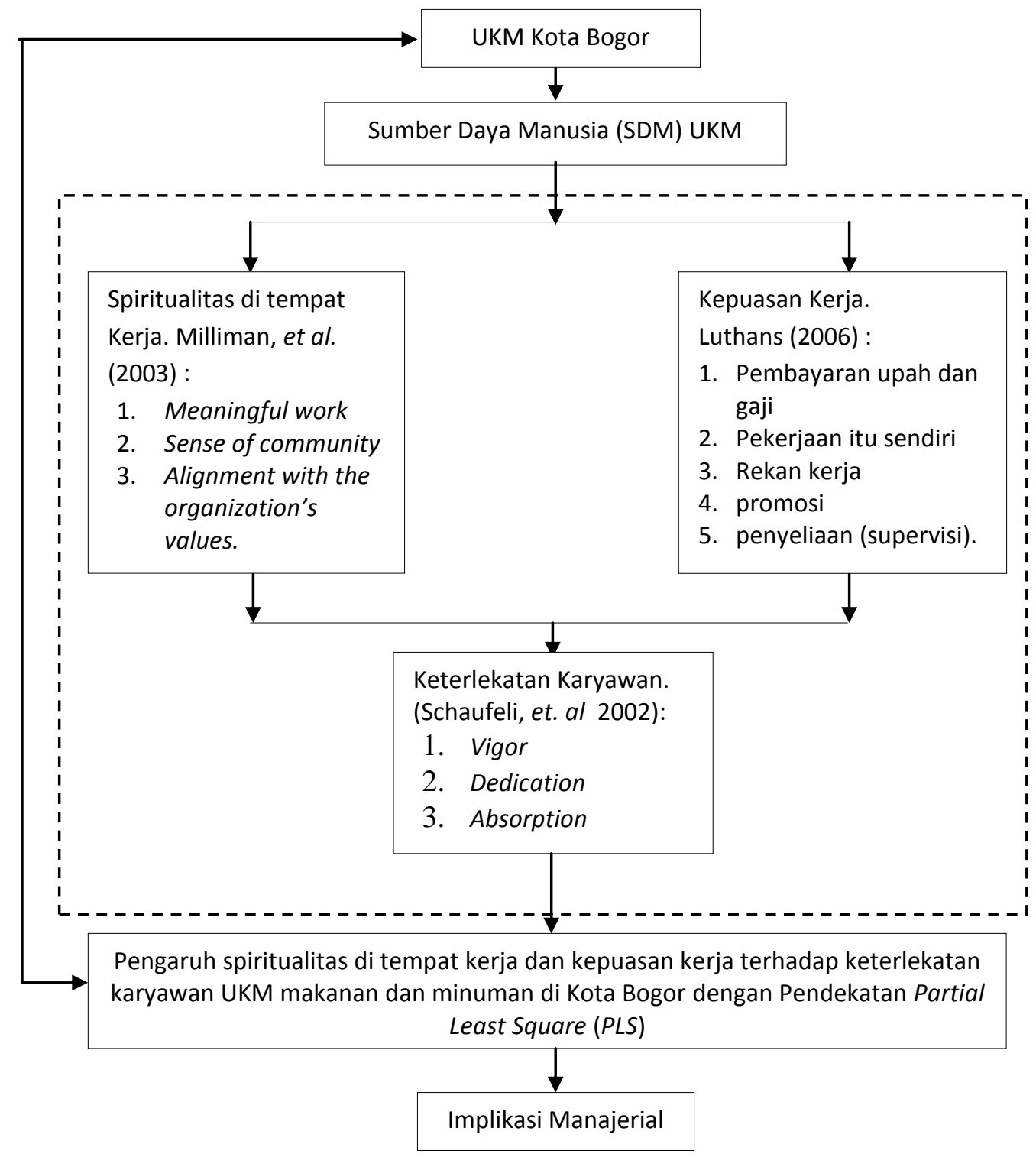

Gambar 1. Kerangka Pemikiran Penelitian

Berdasarkan penjelasan di atas, dapat digambarkan model penelitian pada objek penelitian dengan pola hubungan sebagai berikut: 


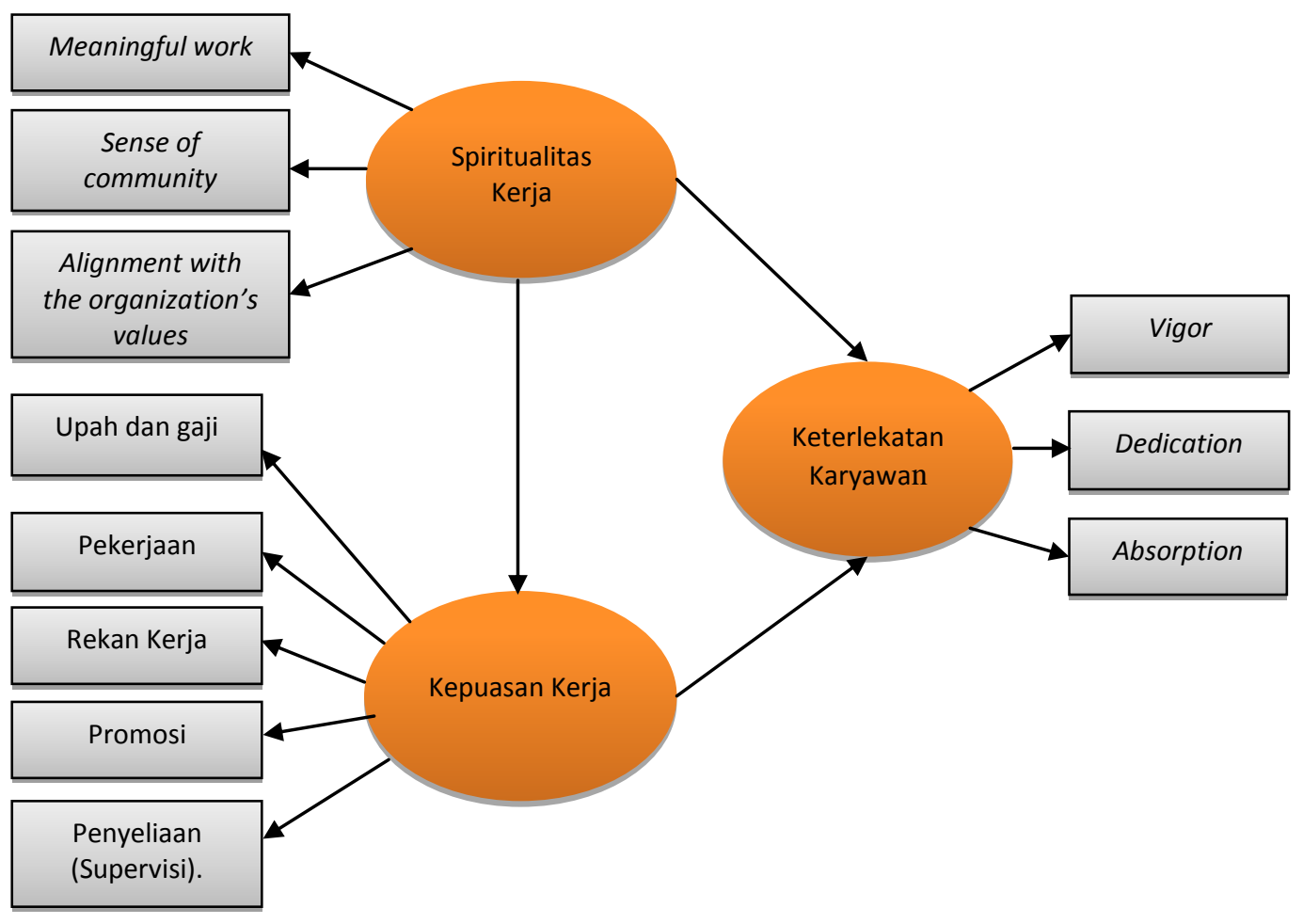

Gambar 2. Penelitian

Hipotesis yang dikembangkan berdasarkan model penelitian melalui pendekatan SEM PLS pada Gambar 2 di atas. Hipotesis pada penelitian ini yaitu:

H1 : Spiritualitas kerja memberikan pengaruh terhadap kepuasan kerja.

$\mathrm{H} 2$ : Spiritualitas kerja memberikan pengaruh terhadap keterlekatan karyawan.

H3 : Kepuasan kerja memberikan pengaruh terhadap keterlekatan karyawan.

\section{Hasil Penelitian}

\section{III.1 Gambaran Umum UKM Makanan dan Minuman Kota Bogor}

UKM klaster Makanan dan minuman merupakan unit usaha dengan jumlah terbanyak jika dibandingkan dengan unit usaha yang lain yakni 198 UKM. Kondisi Kota Bogor yang dijadikan sebagai tujuan wisata menjadikan UKM makanan dan minuman berkembang dengan cepat. Dengan rata-rata omzet per tahun sebesar kurang dari 500 juta rupiah persen. Dan telah berdiri selama selang enam sampai dengan sepuluh tahun. Ini menunjukkan bahwa UKM cukup memiliki pengalaman dalam berwira usaha. Jumlah karyawan untuk sampel UKM pada penelitian ini sebagian besar memiliki enam sampai dengan sepuluh orang karyawan. Hal ini disebabkan karena skala produksi UKM yang dihasilkan masih belum terlalu besar sehingga belum terlalu membutuhkan banyak karyawan. Berdasarkan karakteristik UKM menunjukkan bahwa adanya peluang usaha yang cukup baik di Kota Bogor untuk memulai suatu usaha. 


\section{III.2 Karakteristik Pelaku UKM Makanan dan Minuman terhadap Peubah Spiritualitas Kerja, Kepuasan Kerja dan Keterlekatan Organisasi}

Hasil analisis deskriptif menunjukkan persepsi pelaku UKM terhadap peubah spiritualitas kerja, kepuasan kerja dan keterlekatan kerja seperti yang ditampilkan pada Tabel 1 di bawah ini.

Tabel 1. Karakteristik Pelaku UKM Makanan dan Minuman terhadap Peubah Spiritualitas Kerja, Kepuasan Kerja dan Keterlekatan Kerja

\begin{tabular}{llcc}
\hline No & Indikator & Nilai & Keterangan \\
\hline \multicolumn{2}{l}{ Spiritualitas Kerja } & & \\
1 & Meaningful work & $\mathbf{4 , 5 8}$ & Sangat Setuju \\
2 & Sense of community & 4,51 & Sangat Setuju \\
3 & Alignment with the organization's & 4,48 & Sangat Setuju \\
\hline \multicolumn{2}{l}{ Kepuasan Kerja } & & \\
1 & Pembayaran upah dan gaji & 4,05 & Setuju \\
2 & Pekerjaan itu sendiri & 4,25 & Sangat Setuju \\
3 & Rekan kerja & $\mathbf{4 , 5 7}$ & Sangat Setuju \\
4 & Promosi & 3,78 & Setuju \\
5 & Penyeliaan (supervisi) & 4,38 & Sangat Setuju \\
\hline Keterlekatan Kerja & & \\
1 & Vigor & $\mathbf{4 , 5 7}$ & Sangat Setuju \\
2 & Dedicatio & 4,49 & Sangat Setuju \\
3 & Absorption & 4,42 & Sangat Setuju \\
\hline
\end{tabular}

Sumber:

Berdasarkan Tabel 1 persepsi pelaku UKM memberikan jawaban sangat setuju akan adanya pengaruh spiritualitas kerja terhadap keterlekatan kerja yang dihasilkan dengan nilai terbesar 4,58 pada indikator meaningful work. Hasil dari masing-masing indikator pada peubah spiritualitas kerja juga menunjukan nilai sangat setuju, Hal ini menunjukkan bahwa penerapan spiritualitas kerja penting bagi UKM. Pada peubah kepuasan kerja, secara umum persepsi pelaku UKM juga memberikan jawaban sangat setuju dan setuju terkait dengan pembayaran upah dan gaji, pekerjaan itu sendiri, rekan kerja, promosi pekerjaan, dan penyeliaan (supervisi).

Adapun persepsi pelaku UKM terhadap peubah keterlekatan kerja adalah sangat setuju dengan nilai terbesar 4,57 pada indikator Vigor. Sehingga dapat disimpulkan bahwa pelaku UKM sangat setuju mengenai pentingnya keterlekatan organisasi bagi UKM, sebab karyawan merupakan pelaku utama dalam proses produksi.

\section{III.3 Spiritualitas Kerja dan Kepuasan Kerja terhadap Keterlekatan Karyawan}

Model pengukuran pada penelitian ini dibagi dua, yaitu Outer model yang diinterpretasikan dengan melihat beberapa hal, antara lain nilai konvergen (convergent validity), nilai diskriminan (discriminant validity), composite reliability, Average Variance Extracted (AVE) dan alpha cronbach's (Lattan dan Ghozali 2012). Analisis dengan SEM-PLS pada penilaian konvergen (convergent validity) dilakukan dengan dua tahap. Hasil evaluasi dari model pertama terdapat indikator yang direduksi yaitu KP1 (pembayaran upah dan gaji), KP4 (promosi), KP5 (penyelia), dan KK3 (absorption). Karena pembayaran upah dan gaji, promosi, dan penyelia bagi karyawan UKM klaster makanan dan minuman masih kurang memuaskan dibandingkan dengan indikator 
kepuasan kerja yang lain. Absorption juga kurang merefleksikan keterlekatan kerja bagi karyawan UKM klaster makanan dan minuman.

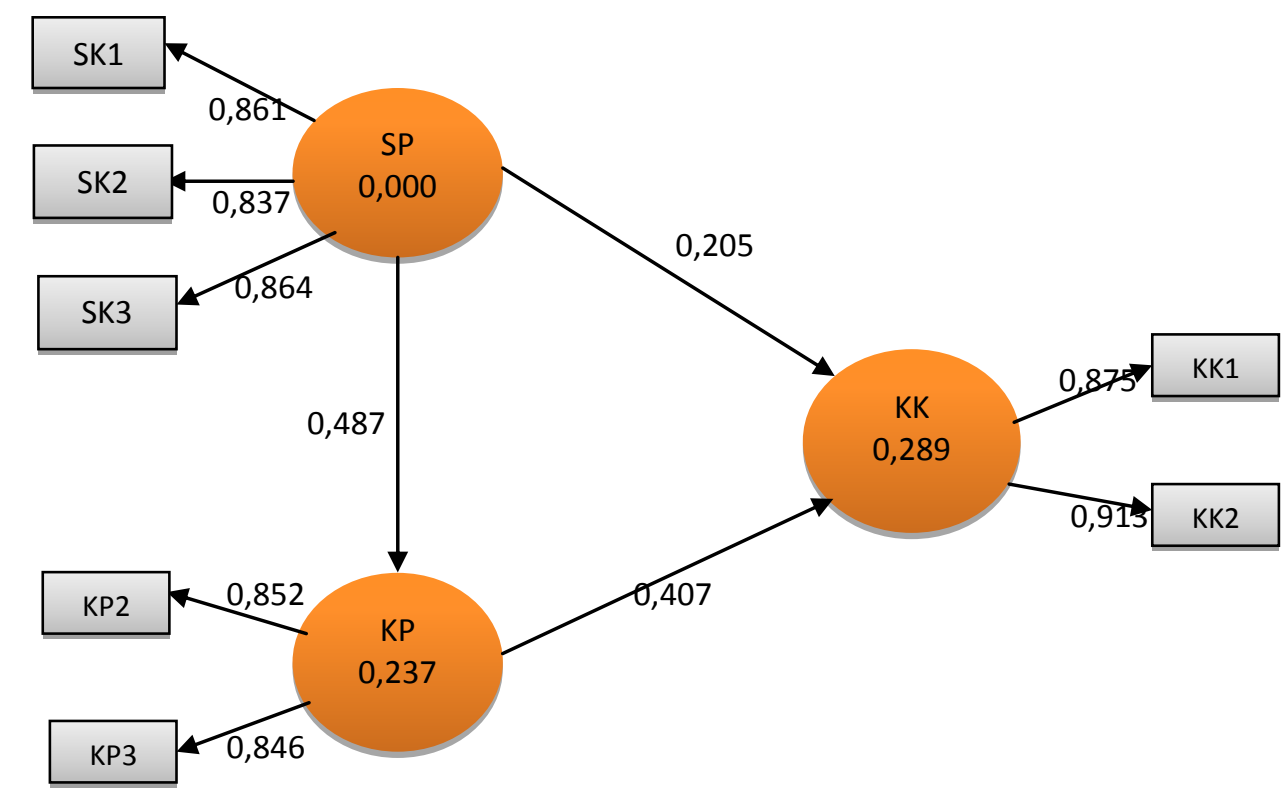

Gambar 3. Tahap kedua (final) struktur model SEM-PLS

\section{Keterangan gambar:}

SK : Spiritualitas Kerja

SK1: Meaningful Work

SK2: Sense of Community

SK3: Alignment with

the Organization's
KP : Kepuasan Kerja
KP2: Pekerjaan itu Sendiri
KP3: Rekan Kerja
KK : Keterlekatan Karyawan
KK1: Vigor
KK2: Dedication

Tahap kedua pengulangan analisis seperti yang terlihat pada Gambar 3 diketahui bahwa seluruh indikator mampu merefleksikan masing-masing variabel. Sehingga dapat dikatakan bahwa spiritualitas kerja berpengaruh terhadap kepuasan kerja dengan nilai koefisien parameter 0,487 dan $t$-value sebesar 5,960, artinya semakin tinggi pemahaman spiritualitas kerja maka akan semakin meningkatkan kepuasan kerja karyawan. Spiritualitas kerja karyawan juga diketahui berpengaruh positif terhadap keterlekatan karyawan dengan nilai koefisien parameter 0,205 dan t-value sebesar 2,197 . Ini berarti bahwa semakin tinggi spiritualitas kerja karyawan maka akan semakin menumbuhkan dan meningkatkan keterlekatan karyawan pada organisasi.

Hal lain yang dapat diketahui adalah bahwa kepuasan kerja berpengaruh positif terhadap keterlekatan karyawan dengan nilai koefisien para meter sebesar 0,407 dan $t$-value sebesar 4,030, jadi semakin tinggi tingkat kepuasan kerja maka karyawan akan semaking melekat dengan organisasi. Penilaian konvergen validitas berdasarkan nilai AVE memiliki nilai cut off di 0,500. Nilai AVE diatas 0,500 menyatakan bahwa validitas konvergen dari indikator baik. Tabel 2 di bawah ini menunjukkan kriteria evaluasi model pengaruh spiritualitas kerja terhadap keterlekatan karyawan melalui kepuasan kerja, sekaligus menunjukkan bahwa model pengukuran dalam penelitan ini memiliki 
validitas dan reliabilitas yang sangat baik dengan nilai composite reliability, cronbach's alpha, dan AVE seluruhnya di atas nilai standarnya.

Tabel 2. Nilai AVE, Composite Reliability, dan Cronbach's Alpha

\begin{tabular}{lccc}
\hline \multicolumn{1}{c}{ Variabel } & AVE & Composite Reliability & Cronbach's Alpha \\
\hline Kepuasan Kerja & 0,721 & 0,838 & 0,612 \\
Keterlekatan Organisasi & 0,799 & 0,888 & 0,750 \\
Spiritualitas Kerja & 0,729 & 0,889 & 0,815 \\
\hline
\end{tabular}

Untuk menguji inner model dilakukan dengan melihat nilai $\mathrm{R}^{2}$ pada konstruk dependen. Variabel laten kepuasan kerja dapat dijelaskan oleh variable laten spiritualitas kerja sebesar 23,70 persen, sedangkan sisanya 76,30 persen tidak dijelaskan oleh variabel lain yang tidak diteliti dalam model penelitian ini. Nilai $\mathrm{R}^{2}$ variabel laten keterlekatan karyawan UKM sebesar 28,90, yang artinya variabel laten keterlekatan karyawan UKM dapat dijelaskan oleh variabel laten spiritualitas kerja dan kepuasan kerja, sedangkan 71,10 persen dijelaskan oleh variabel lain di luar yang diteliti.

Uji selanjutnya adalah dengan melihat signifikansi pengaruh antar konstruk independen (eksogen) terhadap dependen (endogen) dan menjawab apa yang telah dihipotesiskan. Pengujian dengan taraf signifikansi $5 \%$ jika nilai t-statistics $>1,96$, maka hipotesis nol ( $\mathrm{HO})$ ditolak. Nilai t-statistik koefisien pengaruh dari konstruk laten diperoleh dari PLS Bootstrapping. Hasil Model PLS Bootstrapping di penelitian ini disajikan pada Gambar 4:

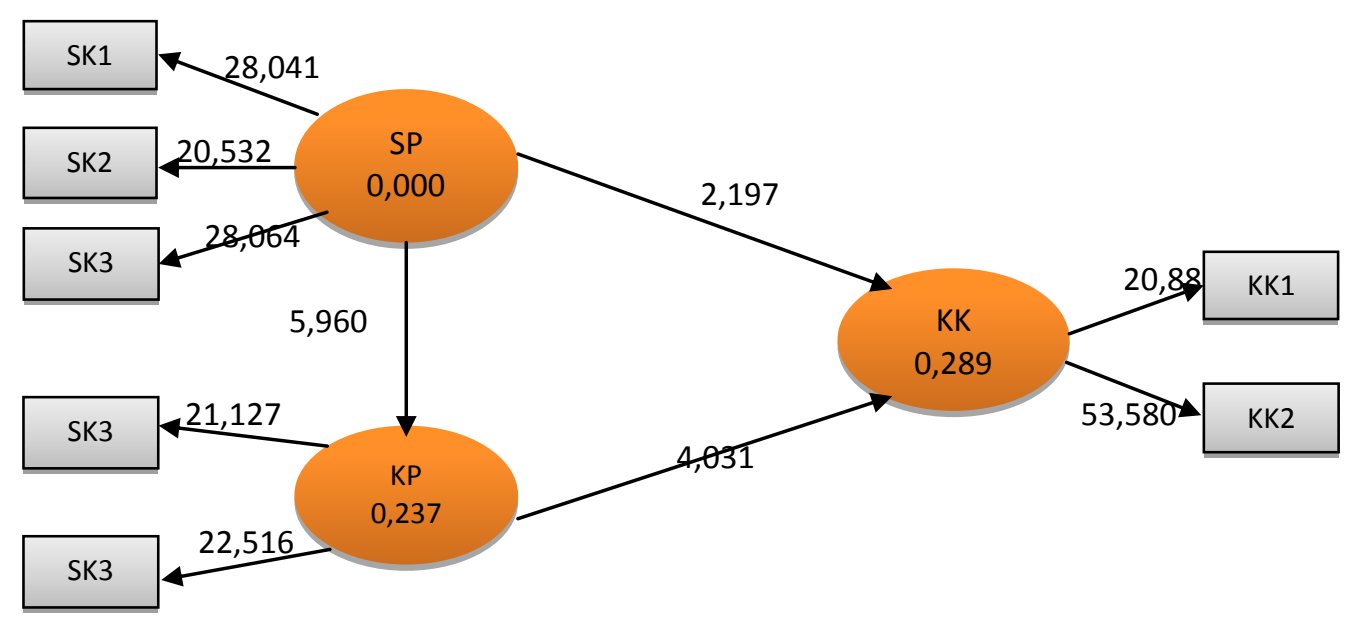

Gambar 4. Model SEM PLS Bootstrappin

Hasil penelitian menunjukkan bahwa spiritualitas kerja memiliki pengaruh yang positif terhadap peubah laten kepuasan kerja dengan nilai koefisien sebesar 0,487 dan signifikan dengan nilai t-hitung sebesar 5,960 lebih dari t-tabel 1,96. Hal ini sesuai dengan penelitian yang dilakukan Kolodinsky et al. (2008) yang menyatakan bahwa Spiritualitas berhubungan positif dengan kepuasan instrinsik, ekstrinsik, dan keseluruhan kerja. Artinya saat kebutuhan spiritualitas seorang karyawan terpenuhi maka akan melahirkan rasa kepuasan. Nurtjahjanti (2010), juga menjelaskan bahwa 
kepuasan dan kepenuhan hidup yang terus diupayakan oleh perusahaan dengan cara memenuhi kebutuhan-kebutuhan psikologis dan spiritualnya, dapat menciptakan atmosfer yang kondusif bagi karyawan untuk bekerja sebaik mungkin. Selain itu, seseorang yang memiliki tingkat spiritualitas yang tinggi akan memiliki sikap lebih positif dalam menjalani kehidupan dan percaya diri serta tidak menyalahkan orang lain, sehingga dalam menghadapi situasi pekerjaan mereka lebih tenang dan bisa melihat hal-hal positif dari pekerjaan mereka sehingga mereka akan merasa lebih puas.

Peubah laten spiritualitas kerja juga memiliki pengaruh yang positif terhadap keterlekatan organisasi dengan nilai koefisien sebesar 0,205 dan signifikan dengan nilai t-hitung sebesar 2,197 lebih dari t-tabel 1,96. Hasil ini mendukung penelitian sebelumnya yang dilakukan oleh Roof (2014) dan Federico (2006) yang menyatakan bahwa spiritualitas kerja memiliki hubungan yang signifikan dengan keterlekatan kerja karyawan. Artinya semakin dalam pengalaman spiritualitas seorang karyawan, maka semakin besar manfaatnya bagi karir mereka, dan juga bagi organisasi tempatnya bekerja. Karena karyawan yang melihat pekerjaan mereka sebagai sarana untuk meningkatkan spiritualitas akan menunjukkan usaha lebih efektif dan efesien, dibandingkan dengan karyawan yang melihat pekerjaannya hanya sebagai alat untuk memperoleh uang. Peran spiritualitas di tempat kerja juga dapat mengarahkan pada kesejahteraan karyawan dan kualitas hidup, membentuk nilai dan keberartian pekerjaan, serta membentuk rasa keterlekatan dan komunitas pada pekerjaan dan organisasi (Karakas 2010).

Kepuasan kerja memiliki pengaruh dan hubungan positif secara langsung terhadap keterlekatan kerja karyawan UKM dengan nilai koefisien sebesar 0,407 dan signifikan dengan nilai t-hitung sebesar 4,030 lebih dari t-tabel 1,96. Hasil penelitian ini sesuai dengan penelitian sebelumnya dari Abraham (2012) dan Gyamfi (2014) yang menyatakan bahwa kepuasan kerja memiliki hubungan yang positif terhadap keterlekatan karyawan. Kepuasan kerja juga merupakan salah satu faktor yang membentuk keterlekatan karyawan (Schiemann 2009). Artinya saat hal-hal mendasar yang dibutuhkan seorang karyawan terpenuhi, maka akan melahirkan perasaan positif karyawan terhadap perusahaan, sehingga karyawan akan mencurahkan seluruh perhatian dan sumber daya yang dimiliki dalam pekerjaannya. Selain itu, karyawan juga akan merasa terikat dan enggan untuk meninggalkan perusahaan secara sukarela. Sebaliknya ketika karyawan merasa tidak puas terhadap pekerjaan maupun organisasi, maka karyawan akan mengungkapkannya dalam beberapa tindakan yang dapat merugikan perusahaan seperti tidak patuh, penurunan kinerja, bahkan pengunduran diri.

\section{Kesimpulan}

Spiritualitas kerja memiliki pengaruh yang positif terhadap kepuasan kerja pada UKM makanan dan minuman di Kota Bogor. Ketika kebutuhan spiritual dan psikologis pada diri karyawan terpenuhi maka akan membuat karyawan merasa puas dan menciptakan keadaan yang kondusif bagi karyawan untuk bekerja sebaik mungkin. Spiritualitas kerja juga berpengaruh keterlekatan karyawan pada UKM makanan dan minuman di Kota Bogor. Penerapan spiritualitas ditempat kerja akan merangsang 
karyawan untuk membentuk persepsi yang lebih positif terhadap organisasi, sehingga menumbuhkan keterlekatan karyawan terhadap organisasi.

Kepuasan kerja memberikan pengaruh yang signifikan dan positif terhadap keterlekatan karyawan pada UKM makanan dan minuman di Kota Bogor. Saat karyawan mendapatkan apa yang dibutuhkan, maka ia akan merasakan kepuasan dalam bekerja dan pada akhirnya akan menumbuhkan ikatan terhadap perusahaan. Hal ini juga dipengaruhi secara tidak langsung oleh penerapan spiritualitas kerja terhadap kepuasan kerja dan keterlekatan organisasi, sehingga penerapan spiritualitas kerja pada UKM makanan dan minuman di Kota Bogor perlu untuk dilakukan karena memberikan pengaruh terhadap kepuasan kerja dan keterlekatan karyawan pada UKM makanan dan minuman di Kota Bogor.

\section{Saran}

Pengelola UKM disarankan untuk mengkomunikasikan dengan jelas maksud dan tujuan menumbuhkan spiritualitas kerja kepada para karyawan, dan meyakinkan para karyawan bahwa mereka bukan hanya sebagai elemen dalam proses produksi tetapi sebagai bagian dari tim. Selain itu, pengelola harus menjadi contoh (role model) bagi karyawan atas perilaku yang diinginkan terjadi di perusahaannya, serta memfasilitasi pembelajaran formal dan informal terkait pemahaman spiritualitas kerja.

\section{Daftar Pustaka}

Abraham S. 2012. Job Satisfaction as an Antecedent to Employee Engagement. SIES Journal of Management, 8(2): 27-28.

[Dinkop UMKM] Dinas Koperasi dan UMKM Kota Bogor. 2013. Rekapitulasi data Usaha Mikro Kecil dan Menengah. Bogor (ID): Kantor Koperasi dan UMKM Kota Bogor.

Federico P.2006. A Correlational Study on How Workplace Spirituality Influences Operational Excellence. A Dissertation Presented in Partial Fulfillment of the Requirements for the Degree Doctor of Management in Organizational Leadership University Of Phoenix.

Gallup Business Journal. 2013. Why Indonesia engage younger workers. http://www.gallup.com.

Gallup Management Journal. 2005. Unhappy workers are unhealthy too. http://gmj.gallup.com.

Ghozali I. 2008. Structural Equation Modeling. Semarang: Badan Penerbit Universitas Diponegoro.

Gyamfi E. 2014 Examining the Effects of Job Satisfaction on Employee Engagement: Applicability in a Small Municipal Government. Thesis. School of Business and Leadership. Nyack College.

Harter JK, Schmidt FL, Hayes TL. 2002. Business-unit-level relationship between employee satisfaction, employee engagement, and business outcomes: A metaanalysis. Journal of Applied Psychology, 87(2):268-279.

Hubeis M. 2011. Prospek Usaha Kecil dalam Wadah Inkubator Bisnis. Bogor (ID): Ghalia Indonesia.

Khrisnakumar S, Neck CP. 2002. The "what", "why", and "how" of spirituality in the workplace. Department of Management, Pamplin College of Bussines, Virginia 
Tech., Blacksburg, Virginia, USA. Journal of Managerial Psychology. 17(3):153164.

Karakas F. 2010. Spirituality and Performance in Organizations: a Literature Review. Journal of Bussines Ethics, 94 (1): 89-106.

Kolodinsky RW, Giacalone RA, Jurkiewicz CL. 2008. "Workplace Values and Outcomes: Exploring Personal, Organizational, and Interactive Workplace Spirituality", Journal of Business Ethics, 81:465-480.

Latan H, Ghozali I. 2012. Partial Least Square Konsep, Teknik dan Aplikasi Menggunakan Program SmartPLS 2.0 M3. Semarang (ID): Badan Penerbit Universitas Diponegoro.

Luthans F. 2006. Organizational Behavior.11. New York (US): McGraw Hill.

Mathis RL, Jackson. 2011. Human Resource Management. Jakarta : Salemba Empat.

Milliman J, Czaplewski, Andrew J, Ferguson J. 2003. Workplace Spirituality and Employee Work Attitudes: An Exploratory Empirical Assessment. Journal of Organizational Management. 16 ( 4):426-447.

Nurtjahjanti H. 2010. Spiritualitas Kerja Sebagai Ekspresi Keinginan Diri Karyawan untuk Mencari Makna dan Tujuan Hidup dalam Organisasi. Jurnal Psikologi Undip. 7 (1): 27.

Roof AR. 2014. The Association of Individual Spirituality on Employee Engagement: The Spirit at Work. Journal of Business Ethics, 596.

Schaufeli WB, Salanova M, Gonzalez-Roma V, Bakker AB. 2002. The measurement of engagement and burnout: A two sample confirmatory factor analytic approach. Journal of Happiness Studies, 3(1): 71-92. 